\title{
The Impact of the Global 2020 Health and Economic Crisis on the Consumption of Students Studying Macroeconomics
}

\author{
Boryana Dimitrova ${ }^{1, *}$ \\ ${ }^{1}$ South-West University "Neofit Rilski", Faculty of Economics, Department of Economics, 2700 \\ Blagoevgrad, Bulgaria
}

\begin{abstract}
.
Research background: 2020 is the first year in recent human history with unprecedented closure of educational institutions and businesses for an extended period of time during the school year. The closure was not the result of military action, but of regulations aimed at stopping the spread of a disease, which at first glance seemed unusually dangerous. This required the learning and work processes to take place in people's homes and not in the buildings of educational institutions and companies. It also affected the usual individuals' consumption of goods. For the optimal recovery of the national and world economic and educational systems, it is necessary to have a variety of information about the impact of the crisis on different groups of the population.

Purpose of the article: This article aims to present the results of a study of changes in consumption, financial and employment status of students studying macroeconomics at a small Faculty of Economics in Southeast Europe.

Methods: The method of the self-administered survey, conducted through Google Forms, disseminated through closed Facebook groups, used for educational purposes, as well as direct sharing of links via Messenger, Viber and e-mail was used.

Findings \& Value added: The changes in the expenses related to the consumption of key goods by the respondents, their financial and employment status have been identified and discussed. The accumulation of knowledge about living in times of crisis is discussed and the readiness of the respondents to purposefully study crisis management is established in view to the optimal formation of the human capital of the nation and the world.
\end{abstract}

Keywords: global crisis; education, consumption, crisis management, human capital

JEL Classification: $A 22 ; A 23 ; F 69 ; H 12 ; O 15$

*Corresponding author: $\underline{b}$ dimi@abv.bg 


\section{Introduction}

For the first time in decades a virus causes mayhem with not only health, but economic, educational, social and even political consequences for the global community. At the end of 2019 the world faced COVID-19 with relative neglect, which quickly turned into serious measures aimed at stopping its spread. National media channels, as well as personal blogs, vlogs, private e-newspapers and news-sites bombarded the public with frightening data. National executive coronavirus control headquarters were formed and started action plans and in almost every country a lockdown was issued. The world, or at least its economic machine, almost stopped turning due to this geopolitical crisis phenomenon as per the classification given by Filipova [1].

Globalization and global interdependence are a main characteristic of modern life. They are based on and impossible to continue without free movement of people, goods, capitals, technological advancement, incl. internet and e-trade, formation of international organizations. The COVID-19 lockdowns limited severely that free movement and as such devastated the economic plans of most business owners and the budgets of the affected countries, severely disrupted the normal operations in health and educational institutions. As per the recommendations of Ulmer, Sellnow \& Seeger [2] for implementation of crisis management systems: anti-crisis plans were rapidly developed and the planned practical measures were immediately enforced. And that had its own costs, incl. on the democracy. Afsahi et al. [3] presented five key insights about democracy enacting both during and after the lockdown; they summarize that COVID-19 has had corrosive effects on already endangered democratic institutions, has revealed alternative possibilities for democratic politics in the state of emergency, has amplified the inequalities and injustices, has demonstrated the need for institutional infrastructure for prolonged solidarity, has highlighted the predominance of the nation-state and its limitations.

But other authors like Anttiroiko [4] describe another part of the global picture - the successful government responses to COVID-19, emphasizing that the management of the crisis is essentially a multi-level governance issue and that cities have important role with the focus put upon urban safety. Other scientists [5-6] report reduction in air pollution, which is also a benefit from the lockdown measures.

Other scientific studies of importance are those of consumers' preferences. Laguna et al. [7] studied the evolution of people's internet searches, the characteristics of the most watched YouTube videos, and Tweeted messages in relation to COVID-19 and food. They found out that Spanish consumers bought pasta, vegetables, nuts, cheese, and chocolates more frequently during the lockdown. Hall et al. [8] studied the consumption displacement in New Zealand related to COVID-19, confirming stockpiling behaviours. Pellegrini et al. [9] reported increased consumption of snacks, unhealthy foods, cereals, and sweets by obesity patients with a higher weight gain during the isolation in Italy. Chodkiewicz et al. [10] surveyed alcohol consumption as stress related coping strategy in Poland during the 2020 spring lockdown. They reported that more than $30 \%$ of respondents changed their drinking habits: $14 \%$ drinking more, $16 \%$ drinking less. Nadkarni, Kapoor \& Pathare [11] focused on the acute non-availability of alcohol in India during the lockdown and its consequences: withdrawals, black marketing of alcohol, suicides. Aruga, Islam \& Jannat [12] studied the plummet of energy consumption in India during the COVID-19 crisis and so on.

In this light, it would be interesting to follow the change in consumption behaviour of Bulgarian students due to COVID-19 crisis, as well as their employment and financial status, with a main focus on the crisis-knowledge they acquired and one they would like to receive in order to be happy citizens and effective managers in future. 
The current students are the human capital of the future. According to Yusof \& Kalirajan [13] the human capital is a significant factor influencing changes in economic growth. Other authors [14-17] focus on the sustainable development of human resources through lifelong learning, training, and education and its importance for business organizations, governments, and international institutions in the light of ongoing globalization. Svabova et al. [18] write about the insufficient link of the education process with the needs of the labour market being one of the main distinctive features of unemployment in Slovakia. Svabova, Durica \& Kliestik [19] model the costs of unemployment of young jobseekers in Slovakia and conclude that the internship program "Graduate Practice" (in essence a work-study program) has mitigated the burden of youth unemployment on Slovakia's state budget.

From this perspective, it is of importance to educate the learners on effective anti-crisis measures for both their personal and their business life, which could minimize the risks of social erosion, long-term unemployment, and others and reduce the burden on the states' budgets.

\section{Methodology}

A self-administered survey instrument was developed to gather anonymously information from student respondents about the changes in their consumption, employment and financial status during the spring lockdown months of 2020.

The first section of the questionnaire gathered demographic and educational information about the age, gender and permanent residence of the respondents, their current finished level of education and specifics about their ongoing university education.

The second section of the questionnaire focused on the employment and financial status of the respondents prior and during the coronavirus lockdown.

The third section of the questionnaire was aimed at gathering information about the changes in respondents' consumption during the 2020 spring coronavirus lockdown and also their viewpoints for the future.

The forth section of the questionnaire was aimed at gathering information about the crisis-knowledge the respondents gathered during the lockdown and their attitude about its expansion in the future.

The process of conducting the survey was challenged by the health risk, raised by the COVID-19, which led to full transfer of the educational process in Bulgaria to online platforms and in such a way the survey had to be carried through. Respondents were selected from a single university in South-West Bulgaria due to the limitations of the coronavirus lockdown and the summer break.

The survey was prepared as a Google-Form questionnaire and the link was distributed through closed Facebook groups, used for educational purposes, as well as direct sharing of the link via Messenger, Viber and e-mail at the end of the second semester of 2019-2020 academic year to freshmen enrolled at the Faculty of Economics, who have studied microand macroeconomics that same year. At the beginning of 2020-2021 academic year a second phase of response-collection was conducted through the distribution of the survey link via e-mails towards all other bachelor students at the Faculty of Economics. 137 usable questionnaires were collected.

\section{Results}

\subsection{Demographic and educational profile of the respondents}


By the criterion of gender, the respondents are respectively: 75\% (103) - women, 25\% (34) - men.

Their age distribution by groups is as follows: $76 \%$ (104) belong to the age group of 18 to 24 -year-old, $13 \%$ (18) - to the age group of 25 - to 34 -year-old and the rest $11 \%$ (15) are older than 34 years.

They live in: a town - 68\% (93), a rural area - 24\% (33) and in the capital - 8\% (11).

By the criterion of completed education: $93 \%$ (128) of the respondents have completed only secondary school and the rest 7\% (9) have at least one Bachelor's degree.

The respondents are currently enrolled: 96\% (132) - in a Bachelor's programme and 4\% (5) - in a Master's programme.

\subsection{Employment and financial status of the respondents}

Prior to the coronavirus lockdown, the respondents received their livelihood mostly from: their family - 59\% (81), their employer - 39\% (54), their own ventures - 16\% (22), National Insurance Institute (pensions, etc.) - 6\% (7) and other sources $-1 \%$ (1).

Before $13^{\text {th }}$ of March $2020 /$ the day when the lockdown was announced/ the work status of the respondents was as follows: 48\% (66) of them didn't work, $42 \%$ (58) worked with a signed labour contract, 4\% (5) were self-employed and 9\% (12) were otherwise engaged.

Asked, weather they had financial worries before the announcement of the coronavirus lockdown in connection with the assumption that such a lockdown may be announced in Bulgaria /based on the information about China, Italy and other countries/, the respondents stated:

- "No.": 61\% (83),

- "Yes, but I undertook no measures.": 16\% (22),

- "Yes, I took measures.": 23\% (32).

The ones who took measures gave the following clarifications /more than one answer was allowed/:

- "I reduced my expenses": 84\% (27),

- "I increased my savings": 44\% (14),

- "I increased my income through more work": 16\% (5),

- "Other": 3\% (1).

Asked, weather there was a change in their employment status during the lockdown period, the respondents answered /more than one answer was allowed/:

- "No.": 59\% (81),

- "Yes, I lost my job.": 15\% (20),

- "Yes, I worked online.": 9\% (13),

- "Yes, my work hours were reduced.": 7\% (10),

- "Yes, I started additional work, in parallel with my main one.": 4\% (6),

- "Yes, I started work.": 3\% (4),

- "Other.": 6\% (8).

Asked how would they describe the overall financial result of the lockdown for them personally, the respondents answered:

- "I have no significant change compared to the previous period.": $60 \%$ (82),

- "I have a noticeable decrease in income.": $36 \%(50)$,

- "I have a noticeable increase in income.": $4 \%$ (5).

Prior to the coronavirus lockdown, 69\% (94) of the respondents state they had savings, the other $31 \%$ (43) had not. During the lockdown the savings of the 94 aforementioned respondents: "were reduced" to 55 of them, "were completely depleted" to 21 and "were increased" to 5 . 
Asked, weather there they had to take a loan during the lockdown, the respondents answered affirmatively $-20 \%$ (28) and the rest $80 \%$ (109) - didn't. The borrowed money was spent on /more than one answer was allowed/:

- household bills and food - by 25 of the respondents,

- medical bills - by 4 respondents,

- computer/telephone to be used for online education - by 2 respondents,

- urgent repairs - by 4 respondents,

- purchase of fixed assets such as car, home, etc. - by 1,

- starting a business, incl. agricultural activities - by 1 ,

- electrical appliances - by 1 .

During the coronavirus lockdown the respondents took the following measures /more than one answer was allowed/:

- "I increased my savings": 23\% (32),

- "I increased my income through more work": 8\% (11),

- "I reduced my expenses": 76\% (104),

- blanks: $11 \%(15)$.

\subsection{Consumption dynamics of the respondents}

During the 2020 spring coronavirus lockdown the respondents declare they made the following changes in their gross expenses by groups of goods as shown in Table 1.

Table 1. Changes in consumption by percentage and number of respondents.

\begin{tabular}{|l|c|c|c|c|}
\hline \multicolumn{1}{|c|}{ Goods } & Increase & Decrease & $\begin{array}{c}\text { Without } \\
\text { change }\end{array}$ & $\begin{array}{c}\text { Non } \\
\text { applicable }\end{array}$ \\
\hline Main Foods & $53 \%(72)$ & $1 \%(2)$ & $46 \%(63)$ & - \\
\hline Junk Foods and Drinks & $22 \%(30)$ & $47 \%(64)$ & $26 \%(35)$ & $6 \%(8)$ \\
\hline Alcohol, Drugs & $2 \%(3)$ & $25 \%(34)$ & $9 \%(12)$ & $64 \%(88)$ \\
\hline Cigarettes, Tobacco & $14 \%(19)$ & $20 \%(28)$ & $16 \%(22)$ & $50 \%(68)$ \\
\hline Fuel & $15 \%(21)$ & $35 \%(48)$ & $23 \%(32)$ & $26 \%(36)$ \\
\hline Electricity & $42 \%(57)$ & $8 \%(11)$ & $48 \%(66)$ & $2 \%(3)$ \\
\hline Water & $38 \%(52)$ & $9 \%(13)$ & $51 \%(70)$ & $1 \%(2)$ \\
\hline Phone Bills & $26 \%(35)$ & $11 \%(15)$ & $64 \%(87)$ & - \\
\hline Entertainment & $12 \%(16)$ & $52 \%(71)$ & $32 \%(44)$ & $4 \%(6)$ \\
\hline Books & $28 \%(39)$ & $18 \%(25)$ & $48 \%(66)$ & $5 \%(7)$ \\
\hline Education & $26 \%(35)$ & $12 \%(17)$ & $60 \%(82)$ & $2 \%(3)$ \\
\hline Clothing, incl. shoes & $10 \%(14)$ & $43 \%(59)$ & $46 \%(63)$ & $1 \%(1)$ \\
\hline Medical Bills & $50 \%(69)$ & $9 \%(13)$ & $35 \%(48)$ & $5 \%(7)$ \\
\hline Cleaning Agents & $39 \%(53)$ & $12 \%(16)$ & $47 \%(65)$ & $2 \%(3)$ \\
\hline Rental for Housing & $6 \%(8)$ & $15 \%(21)$ & $23 \%(31)$ & $56 \%(77)$ \\
\hline
\end{tabular}

Asked about the changes in their thinking during the COVID-crisis, the respondents confirm as "true at the moment /which is after the lockdown has been lifted/" the following statements: 
- "I realize that I need to have savings for "rainy days".": 93\% (128 of the respondents),

- "I think I have the self-discipline to make savings.": 78\% (107),

- "I think that my income is such that I can save.": 46\% (63),

- "I need to find extra work.": $31 \%$ (43),

- "I need to find a better paid job.": $51 \%$ (70),

- "It is necessary now and in the future to refrain from spending on "junk food", unnecessary clothes and belongings.": 85\% (116),

- "I need to reduce/stop my expenses on vices (alcohol, cigarettes, etc.).: 40\% (55),

- "It is necessary to check on the National Insurance Institute website whether my employer is cheating on me.": $40 \%$ (55).

Asked about their opinion on several statements related to their consumption, the respondents answered as shown in Table 2.

Table 2. Opinions about their consumption by percentage and number of respondents.

\begin{tabular}{|l|c|c|c|c|}
\hline \multicolumn{1}{|c|}{ Statements } & $\begin{array}{c}\text { "Yes, I started } \\
\text { doing it and I } \\
\text { will continue" }\end{array}$ & $\begin{array}{c}\text { "Yes, I did it } \\
\text { recently" }\end{array}$ & $\begin{array}{c}\text { "Yes, I plan } \\
\text { to do it" }\end{array}$ & "No" \\
\hline $\begin{array}{l}\text { For my lifestyle, it } \\
\text { makes more sense to } \\
\text { buy second-hand } \\
\text { appliances and cars. }\end{array}$ & $1 \%(2)$ & $5 \%(7)$ & $30 \%(41)$ & $64 \%(87)$ \\
\hline $\begin{array}{l}\text { I now consider it more } \\
\text { appropriate to live in } \\
\text { rented accommodation } \\
\text { instead of paying off a } \\
\text { mortgage. }\end{array}$ & $1 \%(2)$ & $1 \%(2)$ & $9 \%(12)$ & $88 \%(121)$ \\
\hline
\end{tabular}

\subsection{Crisis-knowledge and the respondents}

Asked whether they could apply the knowledge gained from the COVID-crisis not only in their personal life, but also in their professional life - for example, if they are or become the head of a business unit, 72\% (99) of the respondents answered affirmatively.

Asked about whether they would like to be more in-depth educated regarding the economic crises, the respondents answered:

- "Yes, I started doing it and I will continue": 15\% (20),

- "Yes, I did it recently": 4\% (6),

- "Yes, I plan to do it": 58\% (80),

- "No": $23 \%(31)$.

Asked about whether they would participate in a (elective) course on "Personal Crisis Management", the respondents answered:

- "Yes, if it is free of charge": 43\% (59),

- "Yes, even if it is paid": 8\% (11),

- "No": 49\% (67).

Asked about whether they would participate in a (elective) course on "Crisis Management of the Organization", the respondents answered:

- "Yes, if it is free of charge": $45 \%(62)$,

- "Yes, even if it is paid": $9 \%(13)$,

- "No": 45\% (62). 


\section{Discussions}

The age distribution of the respondents is typical for Bulgarian universities. Womenresponders are 3 times more than men, which is has been typical for recent surveys done in a similar way of the same target group. Most respondents live in a non-capital town, which also reflects the relocation from villages to towns in recent years.

Students, studying for a Bachelor's degree in Economics and Management predominate with $96 \%$, which is a result of administrative limitations related to Master's education, sponsored by the government.

Regarding the employment status of the respondents, the unemployed are expected to predominate, but the percentage of those employed under an employment contract is unexpectedly high (30\%). This is an indication of some financial difficulties in the parental families of the young people, which requires an earlier work-start in order to fill-in the income gap. On the other hand, the earlier accumulation of work experience can be interpreted positively, especially when it is in the profession and will allow for faster career growth.

Typical for students, most of them rely on their families for financial support. Almost half of the respondents didn't work before the March lockdown and nearly $61 \%$ didn't have any financial worries related to eventual impeding closure. That could be interpreted as a relatively carefree life. Only $23 \%$ (32) of the respondents felt worried and took measures mainly by expenses reduction (27), followed by savings increase (14) and work income increase (5). This group of students have clearly followed in advance the basic economic principles they studied in first semester's Microeconomics, which is a good example of applying theoretical knowledge in practice. Interestingly, during the lockdown $76 \%$ of the respondents reduced their expanses, which is also an example of rational thinking and external pressure (of reduced income).

As for their employment status the lockdown had negative effect on $22 \%$ of them, who lost their job (20) or had their work hours reduced (10); but some of the respondents managed to find employment even during the lockdown $-7 \%$. Remarkably, this status doesn't correspond directly with the financial status of the respondents: only $4 \%$ declare income increase, and 36\% - decrease. The latter means that nearly one third of the respondents had their purchasing power reduced, which is to have direct impact on their consumption.

The lockdown had negative effects on the savings of the respondents: out of the 94 who had any money saved, 21 spend them all and 55 severely reduced them. $20 \%$ of the respondents had to borrow money and spent them mainly on household bills and food. This on one hand is positive - the students didn't waste expensive money on unnecessary luxuries, but on the other hand is a red alert: the lockdown had put them in precarious situation of having to borrow money to sustain their life.

The study of Table 1., showing the changes in respondents' consumption during the lockdown, gives a good picture of a mostly rational behaviour of the group as a whole. Most respondents reduced the junk foods and drinks (47\%) and increased the main foods (53\%). Alcohol and drugs consumption was increased only by $2 \%$, but decreased by $25 \%$, which could be attributed to the closing of the night clubs, frequented by the students and the return to their parents' households. As expected for a lot of respondents electricity, water and medical bills went up, because they had to spent some cold months closed at home, studying via electricity consuming devices. Most of the phone bills stayed the same, because in Bulgaria more people than not have unlimited plans. The highest decrease is of entertainment expenses, which is logical since the cinemas, cafes and night clubs, etc. were 
closed during the lockdown. Another serious decrease is of clothing and shoes purchases people just used what they have.

The respondents' answers about the shift in their thinking show them to become more mature in terms of economic thinking. Almost all understand the necessity to have savings and $78 \%$ think they have the self-discipline. This could be interpreted in terms of "there is no better teacher than life, especially the days in crisis". Obviously the respondents had to become more frugal and managed to do so, which gave them the confidence to make the statement about the self-discipline. Positive, in terms of their health and bank account, is the fact that $85 \%$ of the respondents had realized the need of cutting down the junk food, clothes and other belongings and $40 \%$ - the vices.

Good news for the appliance and car sellers, banks and building companies - most of the respondents will buy new equipment and cars (64\%) and won't rent but buy a home, even with a mortgage $(88 \%)$.

Obviously, by the self-assessment of the students, the crisis has been a good teacher and $72 \%$ of them think they could apply the gained knowledge in their life in the future. Most students (total of 77\%) would like to gain more knowledge about the economic crises. Almost half of the respondents would like to take a course on "Personal Crisis Management" and/or "Crisis Management of the Organization", which opens up the opportunities for the university to change respectively their curriculum in order to better prepare the human capital, these students are to be, for the dynamic future.

\section{Conclusions}

The results of the survey show that COVID-19 lockdown had more bad than good effects on the financial and employment status of the respondents. But it also was a good teachermost of the students made sound choices, regarding their consumption during the isolation and shifted their thinking into more rational paradigms for the future. Obviously, they have managed to apply some of the basic economic knowledge, which had been part of their syllabus in micro- and macroeconomics. And they are thirsty for more applicable knowledge. Now, it's up to educators to step up and deliver.

This paper is an outcome of project: RP-B4/20 Research of risk management in the conditions of digital and globalized economy.

\section{References}

1. Filipova, M. (2009). Enterprise management in crisis situations. Blagoevgrad: Univercity Publishing House „Neofit Rilski““.

2. Ulmer, S., Sellnow, T., Seeger, M. (2007). Effective crisis communication: moving from crisis to opportunity. Thousand Oaks: SAGE Publications.

3. Afhashi, A., Beausoleil, E., Dean, R., Ercan, S., Gagnon, J.P. (2020). Democracy in a global emergency five lessons from the COVID-19 pandemic. Democratic Theory-An Interdisciplinary Journal, 7(2), V-XIX.

4. Anttiroiko, A. (2021). Successful government responses to the pandemic: contextualizing national and urban responses to the COVID-19 outbreak in East and West. International Journal of E-Planning Research (IJEPR), 10(2), 1-17.

5. Cameletti, M. (2020). The effect of corona virus lockdown on air pollution: evidence from the city of Brescia in Lombardia region (Italy). Atmospheric Environment, 239, 117794. 
6. Zheng, H., Kong, S., Chen, N., Yan, Y., Liu, D., Zhu, B., Xu, K., Cao, W.X., Ding, Q.Q., Lan, B., Zhang, Z.X., Zheng, M., Fan, Z., Cheng, Y., Zheng, S., Yao, L., Bai, Y., Zhao, T., Qi, S., (2020). Significant changes in the chemical compositions and sources of PM2.5 Wuhan since the city lockdown as COVID-19. Science of the Total Environment, 739, 140000.

7. Laguna, L., Fiszman, S., Puerta, P., Chaya, C., Tarrega, A. (2020). The impact of COVID-19 lockdown on food priorities. Results from a preliminary study using social media and an online survey with Spanish consumers. Food Quality and Preference, 86, 104028.

8. Hall, M.C., Prayag, G., Fieger, P., Dyason, D. (2020). Beyond panic buying: consumption displacement and COVID-19. Journal of Service Management, forthcoming article.

9. Pellegrini, M., Ponzo, V., Rosato, R., Scumaci, E., Goitre, I., Benso, A., Belcastro, S., Crespi, C., De Michieli, F., Ghigo, E. (2020). Changes in weight and nutritional habits in adults with obesity during the "lockdown" period caused by the COVID-19 virus emergency. Nutrients, 12(7), 2016.

10. Chodkiewicz, J., Talarowska, M., Miniszewska, J., Nawrocka, N., Bilinski, P. (2020). Alcohol consumption reported during the COVID-19 pandemic: the initial stage. International Journal of Environmental Research and Public Health, 17(13), 4677.

11. Nadkarni, A., Kapoor, A., Pathare, S. (2020). COVID-19 and forced alcohol abstinence in India: the dilemmas around ethics and rights. International Journal of Law and Psychiatry, 71, 101579.

12. Aruga, K., Islam, M.M., Jannat, A. (2020). Effects of COVID-19 on Indian energy consumption. Sustainability, 12(14), 5616.

13. Yusof, Y., Kalirajan, K. (2020). Variations in economic growth across states in Malaysia: an exploratory analysis. Journal of Economic Studies, forthcoming article.

14. Kicheva-Kirova, M. M., Kirov, S. O. (2015). Development of Human Resources Through Lifelong Learning. Promising Problems of Economics and Management: Collection of Scientific Articles: Proceedings of the International Scientific and Practical Conference "Promising Problems of Economics and Management", (pp. 453456). Montreal: Breeze.

15. Kicheva, M. M., Kirov, S. O. (2015). Education and Training of Specialists at the Contemporary Labour Market. Economics, management, law: problems and prospects: Collection of scientific articles: Proceedings of the International Scientific and Practical Conference "Economics, Management, Law: Problems and Prospects", 1, (pp. 332-335). Coventry: Agenda.

16. Kirov, S. (2017). Sustainable development of human resources through training and education. Naukovi Praci MAUP, 53(2), 69-76.

17. Kicheva, M. (2017). Alternative training as opportunity for the business organizations. Naukovi Praci MAUP, 53(2), 62-68.

18. Svabova, L., Durica, M., Kramarova, K, Valaskova, K., Janoskova, K. (2019). Employability and Sustainability of Young Graduates in the Slovak Labour Market: Counterfactual Approach. Sustainability, 11(16), 4462.

19. Svabova, L., Durica, M., Kliestik, T. (2019). Modelling the Costs of Unemployment for Young Graduates in Slovakia: A Counterfactual Approach. Politicka Ekonomie, 67(5), 552-566. 